\title{
FCC POLICY AND PROCEDURES RELATING TO HEARINGS ON BROADCAST APPLICATIONS IN WHICH A NEW APPLICANT SEEKS TO DISPLACE A LICENSEE SEEKING RENEWAL
}

\author{
ROSEL H. HYDE*
}

\section{Preliminary Statement}

On the twenty-eighth of July, 1965, the Federal Communications Commission issued a "Policy Statement on Comparative Broadcast Hearings" (1965 Policy Statement). ${ }^{1}$ The statement set out certain criteria to be applied in comparative cases, but a footnote to the document stated that it did not attempt to deal with problems raised where an applicant was in a contest with a licensee seeking renewal of his license. $^{2}$ Nevertheless, almost immediately the concepts of the policy statement came into use in situations where a new applicant was competing with a licensee seeking renewal-a development which might reasonably have been expected because the statutory test to be applied in all license cases is the same. ${ }^{3}$

Among other matters, the 1965 Policy Statement promulgated the doctrine that in a comparative situation an applicant not associated with other media interests should be given preferential consideration of primary significance as against applicants having other interests, ${ }^{4}$ and further that an applicant proposing an operation in whicls the owners would actively participate on a day-to-day basis should receive a preference of substantial importance. ${ }^{5}$ Although many stations are owned

* George Washington University Law School, 1925-29; Honorary LL.D. 1967, University of Utah; Honorary Doctorate in Public Service 1974, Brigham Young University. General Counsel, 1945-46, Commissioner, 1946-69, and Chairman, 1953-54, 196669, Federal Communications Commission (FCC). Member of Council, Administrative Conference of the United States, 1968-70. Of Counsel, Wilkinson, Cragun \& Barker, Washington, D.C.

The author is indebted to Ronald L. Young, J.D. 1975, George Washington University, M.A. 1970, Columbia University, B.A. 1968, Stanford University, for his assistance in the preparation of this Article.

1. 1 F.C.C.2d 393, 5 P \& F Radio Reg. 2d 1901 (1965).

2. $I d$. at 393 n.1, 5 P \& F Radio Reg. $2 d$ at 1907 n.1.

3. See note 40 infra and accompanying text.

4. 1 F.C.C.2d at 394, 5 P \& F Radio Reg. $2 d$ at 1901.

5. Id. at 395, 5 P \& F Radio Reg. 2d at 1909. 
by group owners, having been hicensed in accordance with Commission regulations providing for multiple ownership within certain specified limitations, ${ }^{6}$ the possibility that the 1965 Pohicy Statenent might provide the means of restructuring the ownership of broadcast stations throughout the country received scant attention until the issuance in January 1969 of the Commission's decision in WHDH, Inc. ${ }^{7}$ In that case, the management of a station which had been in operation for more than a dozen years, albeit under rather special circumstances, ${ }^{8}$ was displaced by a new applicant.

The opimion of the Commission and a concurring statement in the WHDH case caused alarm and reverberations which still continue. ${ }^{9}$ Many bills were introduced in Congress for the stated purpose of restoring confidence and stability in the industry. In January 1970, the Federal Communications Commission issued a new Policy Statement designed to give renewal applicants with good records a measure of protection as such against coinpeting applicants. ${ }^{10}$ This Statement was overruled on judicial review as depriving competing applicants of adequate hearing rights. ${ }^{11}$ Bills introduced in Congress to alleviate the problem have had generally rough going due largely to the difficulty encountered in attempting to find a method of giving appropriate assurances to the incumbent licensees without at the same time denying new applicants a fair hearing opportunity. Separate bills passed in the House and Senate died with the last Congress. ${ }^{12}$ It now appears that

6. 47 C.F.R. $\S \$ 73.35$ (AM), -.240 (FM), -.636 (TV) (1973).

7. 16 F.C.C.2d 1, 15 P \& F Radio Reg. 2d 411 (1969), aff'd sub nom. Greater Boston Television Corp. v. FCC, 444 F.2d 841 (D.C. Cir. 1970), cert. denied, 403 U.S. 923 (1971).

8. See notes 83-85 infra and accompanying text.

9. See, e.g., Jaffe, WHDH: The FCC and Broadcasting License Renewal, 82 Harv. L. Rev. 1693 (1969); $\$ 3$ Billion in Stations Down the Drain?, Broadcasting, Feb. 3, 1969, at 19.

10. Policy Statement Concerning Comparative Hearings Involving Regular Renewal Applicants, 22 F.C.C.2d 424, 18 P \& F Radio Reg. 2d 1901 (1970).

11. Citizens Comınunications Center v. FCC, 447 F.2d 1201 (D.C. Cir. 1971). See generally Federal Administrative Law Developments-1971, 1972 DURE L.J. 115, 182-94.

12. Broadcast License Renewal Act, H.R. 12993, 93d Cong., 2d Sess. (1974). The bill was reported from the House Committee on Interstate and Foreign Commerce on March 28, 1974, H.R. Rep. No. 961, 93d Cong., 2d Sess. (1974), and passed by the House on May 1, 1974. In the Senate, the measure was reported out by the Commerce Coinmittee on Sept. 27, 1974, S. REP. No. 1190, 93d Cong., 2d Sess. (1974), and passed the Senate as amended on Oct. 8, 1974. The Senate requested a conference on the same date, but the measure "died at the end of the session" because of the refusal of Foreign Commerce Committee Chainnan Harley O. Staggers to send the House bill to conference, 32 CoNG. Q. WEEkLY REP. 3437 (1974). Both versions of the bill required a five-year term for license grants. The House version was designed to assure 
the only possibility of prompt remedial attention must come through re-examination of Commission procedures with respect to comparative hearings.

As a general proposition, it would seem that the hearing process should provide the means of establishing the factual basis for decision through the application of the test provided by law. If, as widely believed in the imdustry, decisions after hearings are not fair to competing parties, and if, for that reason, the results are not consistent with the public interest, there is obviously cause to examine the procedures employed in the hearing process. This Article undertakes both to examine the hearing process of the Commission relating to contests between competing broadcast applicants as it has evolved and to suggest changes in approach as shown to be necessary.

\section{PRE-1965: ThE Johnston Broadcasting DoctRINE}

The Federal Communications Commission is authorized to grant applications for authorizations to construct broadcast stations and to issue licenses, mcluding renewal licenses, only upon findings that public interest, convenience, and necessity will be served by sucli grants. This test was first established in the Radio Act of $1927^{13}$ and has been applicable since 1934 under the current Communications Act of 1934. ${ }^{14}$ Where an application is unopposed, the public interest test becomes a matter of determining whether an applicant is qualified under certain statutory requirements and has presented a proposal whicl is in compliance with the Commission's regulations, including certain regulations applicable to preparation of applications. ${ }^{15}$ Where, however, two or inore applicants file competing or inutually exclusive ${ }^{16}$ ap-

a renewal applicant of success "where overall during the expiring term of its license, it has provided good service ... and its broadcast operations have not been marked by serious deficiencies." H.R. ReP. No. 961, 93d Cong., 2d Sess. 18 (1974). "Good" was defined as equivalent to "substantial" in the 1970 Policy Statement. Id. The Senate bill created a "presuinption" in favor of renewal. See 32 CoNG. Q. WEEKLY REP. 2569 (1974). For a discussion of some of the legislative proposals during the last session, see FCC Broadcast License Renewal Reform: Two Comments on Recent Legislative Proposals, 42 GEo. WASH. L. REV. 67 (1973).

13. Ch. 169, 44 Stat. 1162 (1927).

14. 47 U.S.C. \$\$ 301-29 (1970).

15. See, e.g., Primer on Ascertainment of Community Probleins by Broadcast Applicants, 27 F.C.C.2d 650, 21 P \& F Radio Reg. 2d 1507 (1971); Report and Staternent Re: Commission En Banc Programming Inquiry, 20 P \& F Radio Reg. 1902 (1960).

16. Mutually exclusive applications are those filed "at about the same time for the use of electronically interfering facilities." Anthony, Towards Simplicity and Rationality in Comparative Broadcast Licensing Proceedings, 24 STAN. L. Rev. 1, 3 n.1 (1971). For an excellent discussion of the technical background of frequency allocation, see $i d$. at $7-10$. 
plications for the same operating assignment or channel, this statutory test becomes more complex. The difficulty results in part from the fact that competing applicants often include incumbents, thus raising the question of how much significance slould be attached to the operating records and experience gained by this latter group. The complexity of the selection process is also due to the fact that, where there are competing applicants, any one of which (absent conflict with another application) could be accepted as in the public interest, the apphication of the statutory test is necessarily a comparative matter: "Since the number of channels is limited and the number of persons desiring to broadcast is far greater than can be accommodated, the Commission must determine from among the applicants before it which of them will, if licensed, best serve the public."17

The relative nature of the public interest standard as applicable to comparative hearings early led the courts and the Commission to two logical conclusions about the selection process, as set forth in the landmark case of Johnston Broadcasting Co. v. FCC: $:^{18}$

(1) Since the comparative process focuses on differences between applicants, there necessarily can be no preconceived set of criteria existing apart from and uniformly applied to the facts of each case. $^{19}$

(2) Since the comparative process weighs all material differences between candidates (i.e., differences which reflect on capacity to provide service in the public interest), ${ }^{20}$ the criteria for ordering and evaluating those differences can be given no uniform weights or priorities apart from the facts of each case.

Aside froin suggesting that rehance on preconceived criteria to generate and evaluate evidence was inconsistent with the comparative hearing process, the court in Johnston Broadcasting also suggested two more serious risks:

(1) Rekiance upon such a bst would mean that much immaterial evidence (i.e., evidence upon which no differences existed between the parties) would be gathered, with the result that "the complexity, length and expense of proceedings would be vastly increased wholly umiecessarily."21

17. Federal Radio Commisston, Second ANnual Report 169 (1928).

18. 175 F.2d 351, 357 (D.C. Cir. 1949).

19. Id, at 357-58 (wherein the court emphasized the "difficulty, if not the impossibility, of defining a list of things in respect to which applicants may differ").

20. Id. at 357 (wherein the court stated the Commission's obligation to make findings of fact with respect to every difference, "except those which are frivolous or wholly unsubstantial").

21. Id. at 358. 
(2) Reliance upon such a list would run the risk of reversible error insofar as material differences in some cases might fall outside of the set criteria and thus be excluded from the ultimate findings of fact. ${ }^{22}$

Even though Johnston Broadcasting warned against reliance on an all-inclusive, uniform list of criteria, it was only natural for a number of such criteria to evolve from the cases and to become informally accepted as usual indicators of material differences between applicants. Criteria which would not involve difficult subjective judgments as to fitness and quality of programs would, of course, be preferred by hearing officials. Hence, by the early 1950 's, the following standard comparative criteria had developed:

(1) Integration of ownership and management (i.e., the extent of an applicant's proposed participation in the day-to-day operation of the station);

(2) nature of ownership (i.e., the character and previous broadcast experience of an applicant and the extent of his involvement in the affairs of the principal community of license);

(3) concentration or diversification of ownership (i.e., the extent of an applicant's ownership interest in other mass communications niedia);

(4) previous broadcast record; and

(5) program and staffing proposals.

Since these and other comparative issues with respect to which apphicants might differ were accorded no evidentiary weiglit apart from the facts of a particular case, decisions were reached only after a thorough inquiry into the public interest considerations of the community to be served. Thus, the factors of decisional significance varied from case to case. As between two competing applicants for an AM station, for example, both adequately staffed and proposing programs adequate to meet the needs of the local community, the concentration of ownership issue represented the major difference. In one such case the Commission found that competition in the community would not be encouraged should one of the applicants be licensed, inasmuch as its chief stockholder was also general manager of the other existing local station. ${ }^{23}$ However, another comparative liearing case involving an applicant who also owned an AM station in the same community

22. Id.

23. Carolina Advertising Corp., 6 F.C.C. 230 (1938). 
attached little significance to this factor. ${ }^{24}$ The competition provided by "a number of other radio and television stations" in the prospective community of license was deemed to diminish the importance of this concentration of ownership issue; ${ }^{25}$ at the same time, a competing applicant's previous experience in operating a VHF station in the same community was considered most significant "because [such prior experience] deals with knowledge of a type that can be gained in no other way as to how the facility can best be used in the course of dayto-day operation, to serve the interests and desires of a community."26

In yet a third case (Johnston Broadcasting itself), the Commission looked to the issue of programming, there being no other material differences between applicants. ${ }^{27}$ While both competitors proposed to air contrasting viewpoints on controversial nuatters, the Commission found that the broadcast record of only one exhibited actual efforts in this direction, through such past practices as offering assistance to civic groups in their preparation of local live debates and discussions and as airing such programs during "good listening hours" without charge. ${ }^{28}$

As endorsed in Johnston Broadcasting, all applicants during the pre-1965 period were subject to comparative evaluation on a case-bycase basis with one exception-where renewal applicants were annong competing applicants. Assuming a satisfactory record of past perforinance, this latter group was favored for two reasons. First, as a practical matter, an applicant's past broadcast record was deemed a inore rehable indicator of future service in the public interest than a new applicant's untested proposals. ${ }^{29}$ This approach necessarily meant that the renewal apphicant's past record became the single most important consideration among the standard comparative criteria and was thus accorded a significance independent of the facts of any particular case. Second, as a inatter of public policy it was deemed desirable to reward incumbents for good public service with certainty of renewal:

When a broadcasting station has been constructed, necessarily at considerable cost, and has been maintained and operated to the satisfaction of its listeners, it is ordinarily in the public interest that the station continue to operate, and a renewal of its license should not be refused un-

24. Television Broadcasters, Inc., 27 F.C.C. 727 (1959).

25. Id. at 760 .

26. Id. at 761 .

27. Johnston Broadcasting Co., 12 F.C.C. 517 (1947), aff d, 175 F.2d 351 (D.C. Cir. 1949).

28. Id. at 524 .

29. Hearst Radio, Inc. (WBAL), 15 F.C.C. 1149, $1175-76$ (1951). 
less there exist as a basis for the refusal what this court has called "compelling reasons."30

As the argument goes, the incentive of almost certain renewal encourages qualified persons to become and remain broadcast licensees; this in turn is reflected in better service to the community of license. On the other hand, to place the incumbent on a par with new applicants is to subject the former to the "pretensions of a newcomer, which can mold its claims to achieve superiority in a certain area over its opponent whose case is to a large extent frozen by its current operation."31 The uncertainty of this situation might discourage qualified broadcasters from remaining in the field while serving as "an inducement to the opportunist who might seek a license and then provide the barest minimunr of service which would permit short run maximization of profit, on the theory that the license might be terminated whether le rendered a good service or not."32

In short, this bias was intended to equalize the competitive position of the incunbent, who is tied to his past record of performance, vis-à-vis the new applicant, who is free to fashion more desirable, albeit untested, proposals. The effect, however, was more extreme, for the renewal applicant came to have "virtually imsuperable advantage on the basis of his past broadcast record per se."33 Hearst Radio, Inc. $(W B A L)^{34}$ is a typical case in point. Here the new applicant, Public Service Radio (PSR), was preferable to incumbent Hearst on the basis of the following standard criteria:

(1) Integration of ownership and management (one of PSR's principal stockholders would take a very active part in the operation of the station while there existed no such personal involvement by Hearst's stockholders);

(2) nature of ownership (PSR's stockholders were much more personally involved in local civic activities and exhibited a greater diversification in background); and

(3) diversification of ownership (Hearst, besides having ownership or control of newspapers and periodicals across the country, was

30. WOKO, Inc. v. FCC, 153 F.2d 623, 629-30 (D.C. Cir.), rev'd on other grounds, 329 U.S. 223 (1946).

31. Wabash Valley Broadcasting Corp. (WTHI-TV), 35 F.C.C. 677,709 (1963).

32. Policy Statement Concerning Comparative Hearings Involving Regular Renewal Applicants, 22 F.C.C.2d 424, 425, 18 P \& F Radio Reg. 2d 1901, 1904 (1970).

33. Citizens Communications Center v. FCC, 447 F.2d 1201, 1208 (D.C. Cir. 1971).

34. 15 F.C.C. 1149 (1951). 
a licensee of broadcast facilities in three different communities; PSR's stockholders had no ownership interest in any broadcast station). ${ }^{35}$

Despite PSR's superiority in the above criteria and Hearst's "unexceptional record of past programming performance,"36 Hearst's license was renewed because its programming constituted a known quantity in the public interest "when coinpared to the risks attendant on the execution of the proposed programming of Public Service Radio Corporation, excellent though the proposal inay be." 37

The only serious challenge to this liberal renewal practice was made on the substantive ground that it constituted a violation of statutory language in section 307(d) of the Communications Act of $1934,{ }^{38}$ which provided that "action of the Commission with reference to the granting of such application for the renewal of a license shall be limited to and governed by the same considerations and practice which affect the granting of original applications." ${ }^{\text {"39 }}$ Despite the force of this contention, the Commission was able to argue that new and renewal applicants were in fact adjudged on the same ultimate consideration, i.e., the consideration of public interest, convenience, and necessity:

Although this section might be given such a literal construction as to eliminate from consideration the record of an existing licensee seeking renewal when in a comparative hearing with a new applicant, we do not believe that such limited interpretation would be consonant with the overriding requirement of the Communications Act that the public interest be the controlling consideration in the Commission's determination. So viewed it is inanifest that the Commission cannot disregard the record of a licensee any more than it could ignore any other pertinent indicia. ${ }^{40}$

In apparent recognition and tacit endorsement of this tilt in favor of the imcumbent, ${ }^{41}$ Congress shortly after Hearst removed the embarrassing language of section 307(d) and replaced it with the more general requirement that new and renewal applications alike be evaluated ac-

35. Id. at $1180-81$.

36. Id. at 1177 .

37. Id. at 1183.

38. Communications Act of 1934, ch. 652, § 307(d), 48 Stat. 1084, as amended, 47 U.S.C. $\$ 307$ (d) (1970).

39. Id.

40. 15 F.C.C. at 1175.

41. H.R. Rep. No. 1750, 82d Cong., 2d Sess. 8 (1952), in which the Committee on Interstate and Foreign Commerce concluded that the language removed "is neither realistic nor does it reflect the way in which the Commission actually has handled renewal cases." 
cording to the public interest, convenience, and necessity. ${ }^{42}$ It was not until two decades later that this practice was successfully challenged, this time on procedural grounds. ${ }^{43}$

\section{AND THEREAFter: A SEARCH For Stability}

By the late 1950's the Commission practice of weighing all material differences and according relative weights on a case-by-case basis began to show signs of strain. In several dissents by then junior Circuit Judge David Bazelon of the District of Columbia Circuit Court of Appeals, ${ }^{44}$ the diversification of ownership issue was characterized as "one of the basic underlying considerations in the enactment of the Coinnunications Act," ${ }^{\prime 45}$ and thus a more important factor in the selection process than such other comparative criteria as proposed programming. For example, Judge Bazelon argued in Tennessee Television, Inc. $v$. $F C C^{46}$ that the Commission's award of a new license to an applicant, whose broadcasting experience and prior record of service were deenred to outweigh the integration and diversification preferences awarded a conpetitor, "effectively nullified the diversification and antimonopoly policy" of the Commission, since attributes of the favored applicant were the "by-products of concentration." 47 In slort, there is the novel suggestion here, ultimately to be accepted by the Commission, ${ }^{48}$ that

(1) diversification of ownership is a nnatter of basic Commission policy and hence can be accorded a high degree of importance apart from the facts of any specific comparative competition; and

(2) diversification of ownership, if it is an issue, should be accorded a preference over broadcast experience or prior service where the latter two criteria are the product of an applicant's other media interests.

42. 47 U.S.C. $\S 307$ (d) (1970) (originally enacted as Act of July 15, 1952, ch. 879, $\S 5,66$ Stat. 714).

43. Citizens Communications Center v. FCC, 447 F.2d 1201 (D.C. Cir. 1971).

44. Tennessee Television, Inc. v. FCC, 262 F.2d 28, 32 (D.C. Cir. 1958); Pinellas Broadcasting Co. v. FCC, 230 F.2d 204, 209 (D.C. Cir.), cert. denied, 350 U.S. 1007 (1956).

45. Tennessee Television, Inc. v. FCC, 262 F.2d 28, 32 (D.C. Cir. 1958), quoting Multiple Ownership, F.C.C. Report and Order, 18 Fed. Reg. 7796, 7797 (1953); Pinellas Broadcasting Co. v. FCC, 230 F.2d 204, 211 (D.C. Cir.), cert. denied, 350 U.S. 1007 (1956), quoting Multiple Ownership, supra at 7797.

46. 262 F.2d at 32 .

47. $I d$.

48. Policy Statement on Comparative Broadcast Hearings, 1 F.C.C.2d 393, 394, 396, 398, 5 P \& F Radio Reg. 2d 1901, 1908, 1910, 1912 (1965). 
That such a reassessment of the Johnston Broadcasting doctrine had begun at the Commission was acknowledged as early as 1956 by the majority in Pinellas Broadcasting Co. v. FCC. ${ }^{49}$ By 1960, the diversifification of ownership issue appeared to have taken on primary significance with the majority of the Commissioners, at least insofar as new competing applicants were concerned..$^{50}$

Even before the ownership issue had begun to assume greater quantitative significance in the weighing with other comparative criteria, it had undergone a qualitative change. In early cases, it primarily involved concentration of media ownership, i.e., the likelihood of monopolization of media interests of a given community in the hands of a single applicant." ${ }^{51}$ Such an allegation could be rebutted by a showing of intense competition in the community sufficient to preclude such a concentration and to assure a diversity of ideas. ${ }^{52}$ By the 1950's, the ownership issue had expanded to include diversification of control, a positive policy of assuring maximum diversity of ideas through the diffusion of media ownership. ${ }^{53}$ This criterion was

49. 230 F.2d 204 (D.C. Cir.), cert. denied, 350 U.S. 1007 (1956). Judge Prettyman, writing for the majority, stated in passing, "In the case at bar there appears some suggestion that the Commission has changed, or is changing, its view as to the dominant importance of local ownership and as to the evil of a concentration of the media of mass information." Id. at 206.

50. See Commissioner Robert E. Lee's dissent in Young People's Church of the Air, Inc., 28 F.C.C. 617, 623 (1960), vacated, 36 F.C.C. 1127 (1964), in which he objected to the overemphasis given the diversification issue by the majority, contrasting it to past practice where it was "only one of the factors to be weighed and considered in a coinparative proceeding." Id. at 624 . The Commissioner instead took the traditional view that, in light of the ultimate goal of service to the public, there was no danger to diversity of viewpoint where the concentrative effect of multiple ownership would be precluded by the existence of a large number of competing stations in the same community. Id. at 621.

51. See Carolina Advertising Corp., 6 F.C.C. 230, 235 (1938); Woto Knight, Jr., 4 F.C.C. 182, 185 (1937); cf. East Tex. Broadcasting Co. (KGKB), 2 F.C.C. 402, 40809 (1936).

52. See, e.g., Television Broadcasters, Inc., 27 F.C.C. 727, 759 (1959), where the significance of a "slight preference" awarded to applicants opposing the owner of a Beaumont, Tex., radio station was "minimized" by the fact that three other stations were operating in the city. See also Wabash Valley Broadcasting Corp. (WTHI-TV), 35 F.C.C. 686,710 (1960) (hearing examiner), affd, 35 F.C.C. 677,1 P \& F. Radio Reg. 2d 573 (1963), where a hearing examiner rejected the diversification issue raised against multiple owner Wasbash because there was "no evidence of any joint policies or joimt operations of both Wabasl's stations and the newspapers, or of any attempts on its part to suppress or distort news, or of its otherwise engaging in undesirable activity by reason of its control of several communications outlets in a single city."

53. On diversification of control, see Grand Broadcasting Co., 37 F.C.C. 803, 809, 3 P \& F Radio Reg. 2d 779, 789 (1964), where the Commission stated: "[O]ur diversification policy is intended to insure that the listening and viewing public will receive 
deemed inherently desirable and, as it was not tied to the question of media competition, was not susceptible to the same defense as concentration of ownership-the existence of intense competition in the commumity of license. ${ }^{54}$ However, it was at first accorded no greater weight than the other comparative criteria, and hence its effect could be offset by preferences earned on other comparative issues. ${ }^{55}$

With the Commission's formulation of the 1965 Policy Statement, however, the diversification criterion was elevated to equal status with "service to the public" (e.g., programming) as one of the "two primary objectives toward which the process of comparison should be directed."56 After the 1965 Policy Statement, diversification of control became in effect the simgle most important comparative criterion, under which a demerit could no longer be offset by preferences from lesser criteria. Under this policy objective, the following factors are considered:

(1) The extent of an applicant's interest in or control of other media; and

(2) the nature of such media, including:

(a) geographical proximity to the community of service;

(b) the extent of coverage in terms of land area and audience size (or circulation in the case of newspapers); and

(c) the significance of other media interests in comparison with competing inedia in their own communities. ${ }^{57}$

Under the original goal of public service, the Commission has included many of the usual comparative criteria:

(1) The extent to which an applicant intends to participate in the active operation of the station (i.e., integration of ownership and management). Within this category, the following sub-criteria are considered:

(a) the amount of time to be spent by the applicant in operation of the station;

(b) the degree of responsibility to be assumed, gauged by formal management positions to be held by the applicant; and

information from diverse and independent sources and its application is not limited to the avoidance of area concentration of control."

54. McClatchy Broadcasting Co., 19 F.C.C. $343,379-80$ (1954). 1958).

55. Id. at 380; Tennessee Television, Inc. v. FCC, 262 F.2d 28, 31 (D.C. Cir.

56. 1 F.C.C.2d at 394, 5 P \& F Radio Reg. 2d at 1908.

57. Id. at 394-95, 5 P \& F Radio Reg. $2 \mathrm{~d}$ at 1908-09. 
(c) the attributes of the applicant, including previous broadcast experience and local residence in the principal community of service; ${ }^{58}$

(2) the programming proposed; 59

(3) past broadcast records; ;0

(4) efficient proposed use of the frequency; ${ }^{31}$ and

(5) the moral character of the applicant. ${ }^{62}$

In addition to offering a predetermined list of factors upon which differences between applicants could be evaluated, the 1965 Policy Statenient also endowed these factors with relative weights independent of the facts of any particular case. Hence, diversification of control is accorded "primary significance," ship and nranageinent is given "substantial importance," a lesser weight. Under the latter category, full-time owner participation in station affairs is accorded the most credit, while less than "substantial" participation is given no credit. ${ }^{65}$ Owners occupying staff positions in the station organization area are given the greatest credit, whereas consultative positions are given no credit. ${ }^{66}$ Previous broadcast experience is accorded only "minor significance" smce "emphasis upon this elenient could discourage qualified newcomers to broadcasting, and since experience generally confers only an initial advantage." ${ }^{\prime 67}$ On the other hand, local residence for several years in the principal community of service is deemed to have "primary importance";,68 this criterion apparently is grounded on the assuniption that an applicant situated therem has a better grasp of the needs and interests of his community than one living beyond its borders or new to the area.

The 1965 Policy Statement represents the direct antithesis of the doctrine expostulated in Johnston Broadcasting. ${ }^{69}$ While the latter spoke of the "difficulty, if not the impossibility, of defining a list of things in respect to which applicants nuay differ,"70 the forner does just

58. Id. at 395-96, 5 P \& F Radio Reg. $2 \mathrm{~d}$ at 1909-10.

59. Id. at 397, 5 P \& F Radio Reg. 2d at 1911.

60. Id. at 398, 5 P \& F Radio Reg. 2d at 1912.

61. Id., 5 P \& F Radio Reg. 2d at 1913.

62. Id. at 399, 5 P \& F Radio Reg. 2d at 1913.

63. Id. at 394, 5 P \& F Radio Reg. $2 d$ at 1908.

64. Id. at 395, 5 P \& F Radio Reg. 2d at 1909.

65. Id., 5 P \& F Radio Reg. $2 \mathrm{~d}$ at 1909.

66. Id., 5 P \& F Radio Reg. 2d at 1909-10.

67. Id. at 396, 5 P \& F Radio Reg. 2d at 1910.

68. Id., 5 P \& F Radio Reg. 2d at 1910.

69. See notes 18-22 supra and accompanying text.

70. 175 F.2d at 358 . 
that. Instead of determining the relative importance of such criteria on a case-by-case basis as advocated in Johnston Broadcasting, ${ }^{71}$ the Commission assigns thein weights for uniform application in all cases. Moreover, the 1965 Policy Statement goes a step further. While Johnston Broadcasting called for consideration of every material difference between applicants, ${ }^{72}$ the 1965 Policy Statement seeks to limit the introduction of evidence primarily to the three basic ownership criteria automatically designated for liearing: diversification of control, integration of ownership and management, and the owner's local residence in the community of intended service. ${ }^{73}$ Other issues such as proposed programming and past broadcast records must be shown to reflect "material" and "substantial" differences between applicants in order to be designated for hearing. ${ }^{74}$ The burden of offering sucli proof falls on the party seeking designation of the issue and admission of the relevant evidence. In the area of programs, the Commission has already determined the meaning of "material" and "substantial"for program proposals to become an issue, the offer of proof must establish a "superior devotion to public service"; 75 deficient proposals, of course, would be fatal to the applicant under the absolute minimum requirements for individual applicants. ${ }^{76}$ For past broadcast records to be designated for hearing, the offer of proof must establish the extremes of performance, either "unusual" attention to, or failure to meet, the public's needs and interest; ${ }^{77}$ satisfactory performance is ignored as average. ${ }^{78}$ Aside from limiting the volume of evidence for consideration, the 1965 Policy Statement was designed to simplify the hearing process in yet another way-to place primary empliasis upon the "objective" ownership criteria and thus to avoid the difficult subjective determination necessary in comparing programs.

Given the primary goal of simplifying the comparative learing process, it is not unsurprising that, as originally drafted by the Broadcast Bureau, the 1965 Policy Statement was to apply to renewal as well as to new applicants. Objections by several members of the Commission (on the grounds that exclusion of prior broadcast records, except where indicative of "unique" service, would be particularly unfair to

71. Id.

72. Id. at 357.

73. 1 F.C.C.2d at 397, 5 P \& F Radio Reg. 2d at 1911.

74. Id. at 397-98, 5 P \& F Radio Reg. 2d at 1911-12.

75. Id. at 397, 5 P \& F Radio Reg. 2d at 1911.

76. See note 15 supra and accompanying text.

77. 1 F.C.C.2d at 398, 5 P \& F Radio Reg. 2d at 1912.

78. Id., 5 P \& F Radio Reg. $2 d$ at 1912. 
incumbents) led to insertion of a footnote excluding "the somewhat different problems" raised by a renewal applicant from the scope of the 1965 Policy Statement. ${ }^{79}$ Ostensibly suggesting that no aspect of the 1965 Policy Statement would be applicable to renewal applicants, the footnote exclusion was whittled down considerably in Seven (7) League Productions, Inc. (WIII) $)^{80}$ to mean only that, while the same comparative criteria would apply to renewal applicants, "the parties will be free to urge any arguments they deem applicable concerning the relative weight to be afforded the evidence bearing on the various comparative factors." 81 By 1969, this distinction had been further reduced when the Commission maintained that the renewal applicant also was subject to the test of unusual service in order to have his past broadcast record designated for liearing. ${ }^{82}$ On reconsideration of the WHDH decision, both the Commission ${ }^{83}$ and the court of appeals in its affirmation ${ }^{84}$ upheld the origimal decision on the peculiar facts of the case, namely, the fact that the renewal applicant liad operated its station for nearly twelve years on nothing but temporary authorizations, none of which had extended for the normal three-year license period. ${ }^{85}$

The status of renewal applicants remained uncertain because of the failure of the court of appeals to face the real issue liead-on in WHDH, namely, to determine the applicability of the 1965 Policy Statement to this special class of applicants. ${ }^{86}$ However, language in the majority opmion did suggest that, should the court face sucls an issue in the future, it would have doubts on two accounts about exclusion of an incumbent's satisfactory broadcast record under the aegis of the 1965 Policy Statement:

(1) whether the Commission lad "unlawfully interfered with legitimate renewal expectancies implicit in the structure of the Act";87

79. Id. at 393 n.1, 5 P \& F Radio Reg. 2d at 1907 n.1.

80. 1 F.C.C.2d 1597 (1965).

81. Id. at 1599.

82. WHDH, Inc., 16 F.C.C.2d 1, 9, 15 P \& F Radio Reg. $2 d$ 411, 424, aff'd sub nom. Greater Boston Television Corp. v. FCC, 444 F.2d 841 (D.C. Cir. 1970), cert. denied, 403 U.S. 923 (1971). In a strong dissent, Commissioner Lee argued that such a requirement had the effect of applying the same relative weights to incumbents as to new applicants, contrary to the 1965 Policy Statement exclusionary footnote and Seven (7) League Productions. Id, at 24, 15 P \& F Radio Reg. 2d at 435.

83. WHDH, Inc., 17 F.C.C.2d 856, 16 P \& F Radio Reg. 2d 185 (1969).

84. Greater Boston Televisiont Corp. v. FCC, 444 F.2d 841 (D.C. Cir. 1970), cert. denied, 403 U.S. 923 (1971).

85. Id. at 841 .

86. Id. at 854 .

87. Id. 
and

(2) whether "administrative discretion to deny renewal expectancies . . . must not be reasonably confined by ground rules and standards." 88

Perhaps it was this language which encouraged a new group of Commissioners to issue a 1970 Policy Statement, ${ }^{89}$ which in effect reaffirmed the practice applied in Hearst ${ }^{90}$ and Wabash Valley Broadcasting Corp. (WTHI-TV $)^{91}$ of granting an imcumbent with a satisfactory record a controlling preference. However, unlike the earher cases, this Statement unequivocally prescribed a two stage hearing procedure. The sole question during the first stage would concern the imcumbent's past performance. ${ }^{92}$ Competing applicants at this stage could produce only evidence poimting to deficiencies in the renewal applicant's record. Only where the incumbents broadcast record reflected minimal service (the lowest permissible level of service to qualify for renewal in the absence of competition) was the second stage-a full comparative hearingconvened..$^{93}$ It was this procedural format whicl proved to be the Achilles heel of the 1970 Policy Statement, for the District of Columbia Circuit Court of Appeals, in Citizens Communications Center v. FCC, ${ }^{94}$ promptly declared it invalid as violative of section 309(e) of the Coinmumications Act of $1934^{95}$ as interpreted by Ashbacker Radio Co. v. FCC. ${ }^{96}$ While $A$ shbacker involved a comparative hearing between two new applicants, it had come to stand for the general principle in administrative law that "where two or more applications for permits of licenses are mutually exclusive, the Commission must conduct one full comparative hearing of the applications." ${ }^{27}$ As the Citizens Communications Center court rightly pointed out, the first stage, as set forth im the 1970 Policy Statement, "converted the comparative hearing into a petition to deny proceeding." 98 The court went on to indicate, in quoting from Johnston Broadcasting, that a full comparative hearing within the meaning of sections 309(a) and (e) of the Commumications Act of 1934 necessarily involved evaluation of all material differences

\footnotetext{
88. $I d$.

89. 22 F.C.C.2d 424, 18 P \& F Radio Reg. 2d 1901 (1970).

90. See notes 34-37 supra and accompanying text.

91. 35 F.C.C. 677,709 (1946).

92. See 22 F.C.C.2d at 425,18 P \& F Radio Reg. $2 d$ at 1904-05.

93. See id. at 425-26, 18 P \& F Radio Reg. 2d at 1905.

94. 447 F.2d 1201 (D.C. Cir. 1971).

95. 47 U.S.C. $\$ 309(\mathrm{e})(1970)$.

96. 326 U.S. 327 (1945).

97. 447 F.2d at 1211.

98. Id. at $1210 \mathrm{n} .28$.
} 
between competing applicants: "Tlie Commission cannot ignore a material difference between two applicants and make findings in respect to selected cliaracteristics only."

\section{The 1965 Policy Statement: A Retrospective Critique}

While the court in Citizens Communications Center narrowly based its holding on the requirement of a full comparative liearing, ${ }^{100}$ by way of dictum it uncritically endorsed the Commission's 1965 Policy Statement and that Statement's applicability to incumbents. ${ }^{101}$ By so doing, the court ignored the double-edged applicability of Ashbacker and Johnston Broadcasting to the selective admissibility of material evidence practieed under the 1965 Policy Statement. Where evidence is not relevant to one of the few issues automatically designated for hearing, the 1965 Policy Statement places the onerous burden of securing admission of such evidence upon the party offering it. ${ }^{102}$ Aside from this obstacle to a full hearing on all material differences between applicants, there is an even more serious shortcoming regarding the standard for the admissibility of evidence. "Admissible" evidence is that which reflects a material difference between applicants. ${ }^{103}$ Under the pre-1965 doctrine, a "material" difference indicated that one of the applicants was likely to provide better service to the public than another. ${ }^{104}$ Assuming satisfaction by all parties of the minimal prerequisites for individual applicants, the test of "better than" was strictly a relative standard; as such, one applicant's programming-past and proposed-must have been determined to be better than another's, although from an absolute point of view neither's may have been very inspired nor much above the minimum standard for individuals. In contrast, the standard of admissibility (and hence of materiality) for 1949).

99. Id. at 1212, quoting Johnston Broadcasting Co., 175 F.2d 351, 357 (D.C. Cir.

100. 447 F.2d at 1212 n.33.

101. Id. at 1213.

102. See notes 73-78 supra and accompanying text.

103. The offer of proof requirement for all but four of the comparative criteria may discourage applicants from making the effort; furthermore, the 1965 Policy Statement presumes that such an issue, not material when proferred, may not later become material in light of subsequent evidence. In so doing it seemingly places sole responsibility on the applicant to raise such additional issues, this despite the fact that, as the guardian of the public interest in broadcasting, the Commission has an affirmative duty to utilize its own staff and expertise to supplement the record where relevant evidence is not adduced by the parties. Isbrandtsen Co. v. United States, 96 F. Supp. 883, 892 (S.D.N.Y. 1951), aff'd by an equally divided Court sub nom. Rederi v. Isbrandtsen Co., 342 U.S. 950 (1952).

104. Johnston Broadcasting Co. v. FCC, 175 F.2d 351, 357 (D.C. Cir. 1949). 
past program evidence under the 1965 Policy Statement is "unusual" performance; ${ }^{105}$ the standard for proposed program evidence is "superior devotion to public service."106 Both of these standards under the 1965 Policy Statement are not only stricter than the "materiality" test of "better than," they are absolute rather than relative, in violation of the dual requirements set forth in Johnston Broadcasting, namely,

(1) that "[c]omparative qualities and not mere positive characteristics" be considered; $;^{107}$ and

(2) that "an over-all relative determination upon an evaluation of all factors" be reached. ${ }^{108}$

Therefore, on the issue of past and proposed programming, once deemed the "essence of comparative service to the public,"108 the applicant is now in effect denied a full comparative hearing.

The court in Citizens Communications Center also briefly considered congressional intent involving the comparative procedure for treating renewal applicants, in particular the language of section 307 (d) of the Communications Act, as amended in $1952 .{ }^{110}$ In noting that Congress had removed language specifying that renewal applications were to be judged by the "same considerations and practice" as new applications, the court conjectured that such a change was inade "[p]erhaps to guard against the inference that an incumbent's past broadcast record could not be considered at all at renewal time .....111 This court's suggestion is essentially correct, as far as it goes, in light of House ${ }^{112}$ and Senate ${ }^{113}$ Committee Reports explaining the inodification. The Senate Committee Report, for example, stated that the change in statutory language in no way impaired the Commission's "right and duty to consider, in the case of a station which has been in operation and is applying for renewal, the overall performance of that station against the broad standard of public interest, convenience, and necessity."114 "Overall performance" by a renewal applicant in the public interest can only be interpreted to mean past service to the public, the essence of which is past programming, as defined in Johns-

105. 1 F.C.C.2d at 398, 5 P \& F Radio Reg. 2d at 1912.

106. Id. at 397, 5 P \& F Radio Reg. $2 d$ at 1911.

107. 175 F.2d at 356 .

108. Id. at 357 (emphasis added).

109. $1 d$. at 359 .

110. See notes $41-42$ supra and accompanying text.

111. 447 F.2d at 1206 n.13.

112. H.R. REP. No. 1750, 82 d Cong., $2 d$ Sess. 8 (1952).

113. S. ReP. No. 44, 82d Cong., 1st Sess. 7 (1951).

114. Id. (emphasis added). 
ton Broadcasting. ${ }^{115}$ Even more telling is the explanation for amending the language of section 307(d) given by the House Committee on Interstate and Foreign Commerce:

The committee feels that the quoted language [that renewal applicants should be adjudged by the same criteria as new applicants] is neither realistic nor does it reflect the way in which the Commission actually has handled renewal cases. Therefore, this subsection of the bill strikes out the quoted language, and in lieu thereof provides that . . . any renewal applied for may be granted "if the Commission finds that the public interest, convenience, and necessity would be served thereby."116

The above reference to the actual practice of the Commission could only be referring to the comparative criterion of a renewal applicant's past prograin record for the following reasons:

(1) Contemporary cases at that time emphasized the primary importance of programs ${ }^{117}$ and specifically the incumbent's past record of programs ${ }^{118}$ in a comparative evaluation; and

(2) there is no other comparative criterion, inappropriate to the new applicant, which would necessitate deletion of language subjecting both new and renewal applicants to evaluation under the "same considerations and practice."119

After the demise of the 1970 Policy Statement, it can still be argued that the 1965 Policy Statement, now applicable to renewal applicants by virtue of Seven (7) League Productions ${ }^{120}$ and WHDH, ${ }^{121}$ permits consideration of an incuinbent's past broadcast record, ${ }^{122}$ but under limited circumstances. Nevertheless, the 1965 Policy Statement does deny this factor the weight accorded it by Congress in the 1952 amendments to section 307 (d) ${ }^{123}$ and by the Commission itself, which earlier declared the incumbent's broadcast record "indicative of an ability to maintain or improve the acceptable service."124 The court in Citizens Communications Center also acknowledged the importance of this criterion in admitting that "incumbent licensees should be judged primarily on their records of past performance."125

115. 175 F.2d at 359.

116. H.R. Rep. No. 1750, 82d Cong., 2d Sess. 8 (1952).

117. See Johnston Broadcasting Co. v. FCC, 175 F.2d 351, 359 (1949).

118. Hearst Radio, Inc. (WBAL), 15 F.C.C. 1149 (1951).

119. See notes $38-42$ supra and accompanying text.

120. See notes 80-81 supra and accompanying text.

121. See note 82 supra and accompanying text.

122. See note 60 supra and accompanying text.

123. Act of July 15,1952 , ch. $879, \S 5,66$ Stat. 714 . See notes $41-42,112-16$ supra and accompanying text.

124. Hearst Radio, Inc. (WBAL), 15 F.C.C. 1149, 1176 (1951).

125. 447 F.2d at 1213. 
In assessing the 1965 Policy Statement, it is necessary to consider the Commission's current leavy emphasis on the ownership criteria (diversification of media control, integration of ownership and management, and local residence of the owner-applicant), ${ }^{126}$ which are applicable to new and renewal applicants alike. Since "comparative service to the listening public is the vital element,"127 it would seem logical that the relevance and materiality of evidence relating to the ownership criteria be measured in terms of the benefit or harm in an applicant's service to the public, past and prospective. However, under these autonatically designated ownership issues, no sucli showing is necessary; the evidence is apparently assumed to be relevant. The result, illustrated by the decision in Theodore Granik, ${ }^{128}$ can be meaningless as well as arbitrary. There Granik, one of three competing applicants, was accorded a controlling preference on each of the ownership criteria. Specifically, said applicant was found to have been a long-time resident of the intended community of license (the District of Columbia) where he was affiliated with numerous civic, social, and religious organizations. ${ }^{128}$ No effort was made by the Review Board to determine how these factors would assist the applicant in providing better service to the public than his coinpetitors.

The Board also noted that one of the competitors owned two broadcast stations in Puerto Rico and a Spanish language newspaper based in New York City. ${ }^{130}$ This alone was deenned sufficient reason to accord that coinpetitor a demerit on the diversification issue despite the fact that no showing was made as to how this instance of multiple ownership was likely to detract from his service to the District of Columbia commumity, ${ }^{131}$ and despite the fact that his ascertainment of community needs was superior to that of the other applicants. This latter fact itself belies the assumption upon which the preference for local residency and involvement in community affairs is based, namely,

126. 1 F.C.C.2d at 397, 5 P \& F Radio Reg. $2 d$ at 1911.

127. Johnston Broadcasting Co. v. FCC, 175 F.2d 351, 359 (D.C. Cir. 1949).

128. 8 F.C.C.2d 1068, 10 P \& F Radio Reg. 2d 659 (1967).

129. Id. at $1076,10 \mathrm{P} \& \mathrm{~F}$ Radio Reg. $2 \mathrm{~d}$ at $670-71$.

130. Id. at 1073, $10 \mathrm{P} \& \mathrm{~F}$ Radio Reg. $2 \mathrm{~d}$ at 667.

131. In reaching this conclusion, the Board reversed the hearing examiner, who had determined that the applicant's other media interests were irrelevant since they were "geographically removed" from the Washington, D.C. area. In so doing, the Board relied upon the following language of the 1965 Policy Statement: "Other interests in the principal community proposed to be served will normally be of most siguificance, followed by other interests in the remainder of the proposed service area and, finally, generally in the United States." Id. at 1073, 10 P \& F Radio Reg. 2d at 667 (emphasis in original), quoting Policy Statement on Comparative Broadcast Hearings, 1 F.C.C.2d 393, 394-95, 5 P \& F Radio Reg. 2d 1901, 1908-09 (1965). 
that such involvement allows the broadcast owner to better realize the needs and problems of his commumity in order to serve them. Although Granik was granted such a preference, one of his competitorsa permanent resident of New York ${ }^{132}$-was in fact better able to detect the needs of the District of Columbia and prescribe programs to meet those needs. ${ }^{133}$ The Board, however, disregarded this consideration in mechanically applying the 1965 Policy Statement, and it concluded that "the credit accorded under this factor [the superior ascertainment of community needs] is insufficient to overcome the marked preferences accorded the other applicants in the vital areas of diversification and integration." 134 If the Granik case suggests that application of the 1965 Policy Statement bears little or no resemblance to reality, the 1941 Hawaiian Broadcasting Systems, Ltd. ${ }^{135}$ case suggests a factual situation where application of the 1965 Policy Statenient would result in an even more serious rejection of reality. In that case a broadcast license was granted to a party already owning two of four radio stations in the Hawaiian Islands because of its proposal to provide needed foreign language programs to a large number of non-English speaking imhabitants. Consider the possible result in a comparative situation under the 1965 Policy Statement. ${ }^{136}$ One can easily see how the diversification issue, as applied in the Granik case, could control to deny such a valuable program service.

With its enuphasis upon "objective" factors involving ownership patterns, the 1965 Policy Statement is fatally deficient both procedurally and substantively in comparative hearings mvolving both new and renewal applicants. With regard to procedure, the District of Columbia Circuit Court of Appeals has noted that

as a general matter, the federal regulatory agencies should construe pleadings filed before them so as to raise rather than avoid important questions. They "should not adopt procedures that foreclose full inquiry into broad public interest questions, either patent or latent."137

Even inore on point, this same court in Citizens Communications Center declared invalid the Commission's 1970 Policy Statement on

132. 8 F.C.C.2d at 1077, 10 P \& F Radio Reg. 2d at 671.

133. Id. at 1079,10 P \& F Radio Reg. $2 d$ at 673.

134. Id. at $1079,10 \mathrm{P} \& \mathrm{~F}$ Radio Reg. $2 \mathrm{~d}$ at 674.

135. 8 F.C.C. 379 (1941).

136. It is recognized that Hawaiian Broadcasting Systems concerned a single applicant. The facts of the case are borrowed here for the purpose of demonstrating the unfortunate result which could be reached in a comparative situation under the 1965 Policy Statement.

137. Retail Store Employees Local 880 v. FCC, 436 F.2d 248, 254 (D.C. Cir. 1970), quoting Midwestern Gas Transmission Co. v. FPC, 258 F.2d 660, 668 (D.C. Cir. 1958). 
the grounds that preference for the incumbent rendering "substantial" service denies competing applicants a full learing within section 309 (e) of the Commumications Act and Ashbacker. ${ }^{138}$ Likewise, the obstacles raised by the 1965 Policy Statenient to a conparative evaluation of programming, past and proposed, deny both new and incumbent applicants an opportunity to be lieard on the one issue most directly affecting the public interest; while the inethod of ownership may indirectly affect the licensee's capability of serving the needs of his community, it is the nature of the programs themselves which is the essence of that service..$^{139}$

With regard to substance, the Commission, by opting for comparative criteria which avoid the difficult subjective evaluation of programs, is guilty of just that practice described by Professor Davis in his $\mathrm{Ad}$ ministrative Law Treatise: "Perhaps one of the most common deficiencies [of administrative hearings] is the tendency to develop issues of policy as if they were issues of fact."140 Obviously, the Commission has the authority to determine that, as a matter of policy, diversity of viewpoint is in the public interest. ${ }^{141}$ In pursuing this policy, the Commission may consider diversification of control among the comparative factors evaluated in weighing public interest, convenience, and necessity. ${ }^{142}$ It may not as a nuatter of abstract policy, however, presume that diversification of control encourages competition and hence assures a diversity of ideas. This assumes an empirical basis which, by the Commission's own admission, does not exist. ${ }^{143}$ Without such a basis, this confusion of policy and fact lias resulted in an arbitrary determination of the specific means for achieving the ultimate goal-service in the public interest. ${ }^{144}$ The incorrectness of this approach was early

138. $447 \mathrm{~F} .2 \mathrm{~d}$ at 1211-12. See notes $93-98$ supra and accompanying text.

139. See Johnston Broadcasting Co. v. FCC, 175 F.2d 351, 359 (D.C. Cir. 1949).

140. $1 \mathrm{~K}$. Davis, Admistrative LaW Treatise $\$ 8.13$, at 578 (1958).

141. See Citizens Communications Center v. FCC, 447 F.2d 1201, 1213-14 n.36 (D.C. Cir. 1971).

142. Id.

143. In re Policy Statement on Comparative Broadcast Hearings, 6 P \& F Radio Reg. 2d 96a (1965). See also Policy Statement on Comparative Broadcast Hearings, 1 F.C.C.2d 393, 402, 5 P \& F Radio Reg. 2d 1901, 1916 (1965) (Commissioner Hyde, dissenting).

144. Note subsequent Commissioners' dissatisfaction with the diversification issue as a matter of policy, expressed in the 1970 Policy Statement, 22 F.C.C.2d 424,18 P \& F Radio Reg. 2d 1901 (1970), in which the majority concluded that such an issue "should be the subject of general rulemaking proceedings rather than ad hoc decisions in renewal hearings." Id. at 428, 18 P \& F Radio Reg. 2d at 1907-08. See also Columbus Broadcasting Coalition v. FCC, 505 F.2d 320 (D.C. Cir. 1974), in which the Commission decided that, pending a rulemaking proceeding on broadcast licensee ownership of newspapers, it will only consider the diversification issue if the party raising such a 
stated by the United States Supreme Court in FCC v. RCA Communications, Inc. ${ }^{145}$ There the nuajority observed that, while an applicant need not demonstrate tangible benefits derived from the increased conipetition of its entry into the field, "it is not too inucli to ask that there be ground for reasonable expectation that conpetition may have some beneficial effect. Merely to assume that competition is bound to be of advantage . . . is not enough."146 While this particular statenient concerned a common carrier ${ }^{147}$ rather than a broadcast applicant, its significance is nowise lessened, given the fact that licensees in both areas nuust mcet the ultimate test of service in the public interest, are closely regulated by the Commission, and are in fields of communications closed to all but a select number of qualified licensees.

In the limited area of licensee ownership of newspapers, the District of Columbia Circuit appears to have implicitly accepted the Supreme Court's dictum in $R C A$ Communications by requiring that the diversificaton of control issue be raised only where specific abuses by the inultiple owner are alleged.148 In its now defunct 1970 Policy Statement, the Commission sought to go a step further by eliminating the diversification issue entirely from the comparative hearing, finding it more appropriately an issue to be resolved by "general rulemaking proceedings rather than ad hoc decisions in renewal hearings." 149 While the Commission was careful to limit its change of heart to renewal applicants only ${ }^{150}$ - thereby avoiding overruling the 1965 Policy Statement-the reasons given for its decision are equally as valid for new applicants. First, the Commission acknowledged that the diversification issue would have a significant effect on the broadcast industry as a whole, and that such a substantive matter was more appropriately the domain of a general rulemaking proceeding. ${ }^{151}$ Second, the Commission suggested that multiple ownership was an unfair and unsound basis for denial of a license to an otherwise qualified applicant-unfair because the applicant could well be in conformity with the Commission's nultiple ownership rules,; ${ }^{152}$ and unsound because such a policy,

claimed advantage alleges specific facts which tend to show the multiple owner guilty of abuses not in the public interest. Id. at 325 .

145. 346 U.S. 86 (1953).

146. Id. at 97 .

147. See id. at 87-88.

148. Columbus Broadcasting Coahtion v. FCC, 505 F.2d 320, 325 (D.C. Cir. 1974).

149. 22 F.C.C.2d at 428, 18 P \& F Radio Reg. $2 d$ at 1908.

150. Id. at 426-27, 18 P \& F Radio Reg. 2d at 1906.

151. Id. at 427-28, $18 \mathrm{P} \& \mathrm{~F}$ Radio Reg. $2 \mathrm{~d}$ at 1907-08.

152. Il. at 427,18 P \& F Radio Reg. $2 d$ at 1907. 
independent of program service, would tend to discourage qualified applicants from entering or remaining in the broadcast field..$^{153}$

The einphasis upon ownership criteria to the near exclusion of programming issues, ostensibly designed to encourage competition and diversity in the broadcast industry, in effect tends artifically to eliminate differences in the comparative proceeding itself. The Commission in its WHDH decision endorsed limited (only where "unusual") use of an applicant's past record of performance,

for otherwise new applicants competing with a renewal applicant would be placed at a disadvantage if the renewal applicant entered the contest with a built-in lead arising from the faet that it lias a record as an operating station. More importantly, the public interest is better served when the foundations for determining the best practicable service, as between renewal and new applicant, are more nearly equal at their outset. ${ }^{154}$

Previous broadcast experience is accorded "minor significance" because "emphasis upon this element could discourage qualified newcomers to broadcasting . ..."155 In attempting to make new and renewal applicants subject only to those comparative issues which they have in common, the Commission is in effect artifically equalizing their competitive status. The natural comparative advantages which an incumbent may have, based on previous broadcast experience (e.g., more practical program proposals and a more realistic assessment of the financing necessary for the kind of operation anticipated) are virtually ignored. In fact, previous broadcast experience is unconvincingly put down as conferring "only an initial advantage"156 which is "remediable,"157 despite the fact that the Commission had earlier recognized the importance of this factor insofar as "it deals with knowledge ... as to how the facility can best be used in the course of dayto-day operation, to serve the interests and desires of a community."108 This built-in advantage was recognized in Ashbacker ${ }^{159}$ and most recently accepted as a fact of life in Citizens Communications Center, ${ }^{160}$

153. Id. at 428, 18 P \& F Radio Reg. $2 d$ at 1907: "[T]he stability of a large percentage of the broadcast industry . . . would be undermined by such a policy."

154. WHDH, Inc., 16 F.C.C.2d 1, 10 (1969), aff'd sub nom. Greater Boston Television Corp. v. FCC, 444 F.2d 841 (D.C. Cir. 1970), cert. denied, 403 U.S. 923 (1971). 155. Policy Statement on Comparative Broadcast Hearings, 1 F.C.C.2d 393, 396, 5 P \& F Radio Reg. 2d 1901, 1910 (1965).

156. Id. at 396, 5 P \& F Radio Reg. 2d at 1910.

157. Id. at $396 \mathrm{n} .8,5 \mathrm{P} \& \mathrm{~F}$ Radio Reg. $2 \mathrm{~d}$ at $1910 \mathrm{n} .8$.

158. Television Broadcasters, Inc., 27 F.C.C. 727, 761 (1959).

159. 326 U.S. at 332.

160. 447 F.2d at 1213. 
wherein the court admitted that "in a renewal proceeding, a new applicant is under a greater burden to 'make the comparative showing necessary to displace an establshed licensee." "161 For the Commission to de-emphasize these actual comparative advantages, as practiced under the 1965 Policy Statement, is to be guilty of the same inaladministration for which it was criticized in its regulation of common carriers in the recent case of Hawaiian Telephone Co. v. FCC:162

Yet it is all too embarrassingly apparent that the Commission has been thinking about competition, not in terms primarily as to its benefit to the public, but specifically with the objective of equalizing competition among competitors.

This is not the objective or role assigned by law to the Federal Communications Commission. As a result of focusing first on competitors, next on competition, and then on the public interest, the FCC has given scant attention to the question of public convenience and necessity, and therefore has not met its statutorily imposed duty. ${ }^{163}$

The Commission, as regulator of broadcast licensees, likewise has a statutory duty to select applicants who will best serve the public interest. It tends, however, to ignore this fundamental test in the broadcast area by basing its selection process on the general policy of encouraging competition through greater diversification of media control, without tying such an issue to the public interest considerations of the specific case. In Hawaiian Telephone Co. the court remanded the case to the Commission for specific findings that the public interest would indeed be served by granting the applicant authority to engage in expanded service, ${ }^{164}$ the same court, however, has not required such a specific showing under the 1965 Policy Statement. In Granik, the deinerit given a radio applicant for the District of Columbia, because of his ownership of broadcast stations in Puerto Rico and of a national Spanish-language newspaper located in New York City, was based on the fact that his competitors had no other media ownership interests. ${ }^{165}$ Under the doctrine of Hawaiian Telephone, this demerit would have been removed for failure of the Commission to show how the inultiple ownership interests adversely affected that applicant's ability to serve the public interest in the District of Columbia community. As suggested by the court in Hawaiian Telephone, this failure to tie "objective" ownership criteria to specific facts indicative of the public interest

161. Id., quoting Ashbacker Radio Corp. v. FCC, 326 U.S. 327, 332 (1945).

162. 498 F.2d 771 (D.C. Cir. 1974).

163. Id. at 775-76 (emphasis in original).

164. Id. at 777-78.

165. See notes $128-34$ supra and accompanying text. 
is to violate a statutory duty expressed in sections 307(d) and 309(e), inter alia, of the Communications Act. ${ }^{166}$

\section{CONCLUSIONS}

The ultimate issue which the Commission inust address in applying the statutory test where there are competing broadcast applican!s is who will best serve the public interest, convenience, and necessity. To give neaning and purpose to hearings required by law, this test must be applied in the light of the facts of the case under consideration, not in terms of the general public interest in sucl abstract principles as competition, diversity of ownership, and local ownership. The Commission's inquiry inust relate to the needs and characteristics of the particular community which the applicants are competing to serve. It is for this reason that Johnston Broadcasting advocated a case-by-case approach, believing it impossible to measure the effect of proposed service in a community by a set of fixed, preconceived criteria.

The inipossibility of success in such an attempt at uniformity has been shown in the above text. First, evidence generated according to the standardized criteria may be incomplete, for it may ignore the possibility that in a particular case material differences between applicants do not fall within the preconceived comparative categories. Second, the weights attached in the abstract to these preconceived criteria also may not truly reflect the relative priorities of a particular community's needs and hence may fail to realistically ascertain which applicant is best able to satisfy those needs. In short, policy has been substituted for facts, and preconceived objective criteria have pre-empted the statutory test of the public interest. Thus, for example, the automatic preference accorded local applicants disregards the possibility that, depending on the facts of a particular case, a competitor's proposed use of a professional employee-manager from outside the community might very well bring imagination, an appreciation of the role of journalism, and sensitivity to social issues far exceeding that of a particular local owner-manager.

There are two objections which will probably be argued against returning to the case-by-case approach prescribed by Johnston Broadcasting. First, this approach lacks certainty of outconie, which the 1965 Policy Statement seemed to provide. ${ }^{167}$ However, it is this saine

166. 47 U.S.C. $\$ \$ 307$ (d), 309(e) (1970).

167. See, e.g., Jaffe, supra note 9. Professor Jaffe asserted that the 1965 Policy Statement rejected the "fantastic gamesmanship" inherent in the pre-1965 comparative process whereby criteria "so vague and so various that decisions not only unpredictable 
certainty which has threatened the stability of the broadcast industry, a fact recognized by the Commissioners in the 1970 Policy Statement. ${ }^{168}$ Furthermore, it is this certainty which allows the competing applicant to tailor his organization and proposals in sucl a way as to satisfy preconceived preferences and thus prevail over competitors who are either tied to prior records as incumbents or are multiple owners. With all its emphasis upon competition, the 1965 Policy Statement, in effect, would seem to discourage new and renewal applicants from constantly seeking to improve the quality of their service. In short, the comparative test as to which applicant is best able to serve defies preconceived certainties. As stated in Johnston Broadcasting, it is the purpose of the comparative hearing to make such a determination.

The second objection, the difficulty and unwieldiness of comparing all manner of differences between applicants, ${ }^{169}$ is not to be denied: However, the purpose of an administrative hearing is to organize the evidence submitted and to compile a factual record which embodies the material differences between applicants so that a decision can be made which will be fair to the parties and in the public interest.

but often inexplicable" were used to award licenses. Id. at 1695. See also Friendly, The Federal Administrative Agencies: The Need for Better Definition of Standards, 75 HArv. L. Rev. 863, 1055, 1062-68 (1962); Irion, FCC Criteria for Evaluating Competing Applicants, 43 MrNv. L. Rev. 479, 482-83, 489-91 (1959); Schwartz, Comparative Television and the Chancellor's Foot, 47 GEo. L.J. 655, 678-89 (1959).

168. See 22 F.C.C. at 425,18 P \& F Radio Reg. $2 d$ at 1904.

169. See Policy Statement on Comparative Broadcast Hearings, 1 F.C.C.2d 393, 394, 5 P \& F Radio Reg. 2d 1901, 1908 (1965). See also J. LANDIS, RePort on REguLATORY Agencies to THE PResident-Elect 22 (1960) ("Observers of the procedures employed by the [Federal Commumications] Commission agree that the issues litigated are unreal and a mass of useless evidence, expensive to prepare, is required to be adduced." Id. at 53.); Anthony, supra note 16, at 32; Friendly, supra note 167, at 1060. 